\title{
Pré-escola Abelhinha/INPA
}

\author{
A prática da simplicidade \\ no processo educacional
}

A Pré-Escola Abelhinha/INPA foi criada em 1977, com finalidades educacionais ao pré-escolar e suplementação nutricional e saúde às crianças carentes, filhos de funcionários de baixa renda do Instituto.

Situada na periferia de Manaus, no bairro do Coroado II, onde reside a maioria destes funcionários, a população é estimada em aproximadamente 25.000 pessoas de baixo nível sócio-econômico.

A Abelhinha iniciou com 25 crianças e atualmente, de acordo com sua expansão física e aumento de pessoal, a escola atende a 240 crianças na faixa de 4 a 6 anos de idade. Dada a grande procura surgida, o atendimento estendeu-se também às crianças da comunidade, filhos ou não de funcionários do INPA. Todo o atendimento é gratuito.

Além da formação pré-escolar com técnicas específicas, a escolinha tornou-se um centro comunitário, atingindo não só os alunos, mas também suas famílias.

A Abelhinha teve sua primeira "Colméia" numa casa de madeira, simples e pouco espaçosa. Hoje, essa casa ainda existe, mas a "Colméia" tem um pouco mais de quintal e dois pavilhões construídos pelo INPA e SEDUC, respectivamente. Através de promoções sociais, as crianças ganharam novas construções pequenas mas de grande utilidade como o "Chapéu de Palha" (coberto de palhas cie palmeiras, todo aberto, típico da região) que foram construídos pelos pais num fim de semana.

A área escolar foi ampliada, fruto de doações do Governo do Estado do Amazonas e SUFRAMA (Superintendência da Zona Franca de Manaus). Ainda assim, o local é "apertadinho" para a vivacidade infantil dos alunos.

Os poucos móveis que são utilizados na escola foram trazidos do INPA (móveis em desuso), e outros foram doações. A realidade escolar, dentro deste contexto, é semelhante àquela em que a criança vive. Os brinquedos existentes na escola, alguns foram confeccionados pelas mães, como: bonecas, bolas de pano, tapetes. Os demais foram doados pela ASCON, entidade social dos servidores do CNPq/INPA.

Não há separação de salas na escola, tudo é aberto, facilitando inclusive a ventilação muito necessária no clima tropical. Os grupos de crianças que desenvolvem as atividades são formados nas sombras das árvores, em contato com o chão, ou nos tapetes feitos pelas mães.

O material didático utilizado não é sofisticado, mas com o mesmo valor funcional pois fazem parte da realidade da criança. Como os recursos financeiros são escassos, utiliza-se material simples não criando conflitos com o tipo de vida ou condição social própria da criança. São aproveitados os recursos regionais para o desenvolvimento das atividades, tais como: sementes de frutas, juta, cipós, palhas, argila, folhas 
das árvores, goma (feita da mandioca), sucatas em geral, embalagens das indústrias da Zona Franca como isopor, papelão, barbantes, etc. As folhas de papel são restos de material de escritório que são doados à escola.

A decoração do ambiente é toda feita com trabalhos dos alunos, tudo muito colorido e natural, o que, na maioria das vezes, ajuda a disfarçar os buracos da parede. Nada é comprado feito. Tudo é improvisado, desde o balanço (de pneus velhos) ao escorregador de madeira entre as árvores, construídos pelos pais.

Nessa forma simples e modesta, a educação, acima de tudo, desempenha papel preponderante na formação das crianças.

Desde o surgimento da Pré-Escola Abelhinha/INPA, que se tomou o cuidado para não deter-se em um único método ou linha de pensamento restrita. Há um princípio de liberdade e adequação à realidade amazônica, que faz com que a metodologia em ação seja diversificada, voltada principalmente às necessidades individuais das crianças e dentro das possibilidades reais da escola.

A proposta curricular visa a proporcionar situações que favoreçam um desenvolvimento amplo da criança. As atividades são planejadas dentro da visão Piagetiana de que a criança se desenvolve, assimilando e acomodando mais rapidamente, de acordo com a evolução das estruturas genéticas inatas e estimulação ambiental.

Dentro desta abordagem, as crianças são agrupadas em função do nível de desenvolvimento, e as atividades são planejadas de acordo com a capacidade de aprendizagem dos alunos.

As atividades são essencialmente lúdicas porque desta forma as crianças aprendem mais facilmente, confirmando, a expressão usada por H. Baldus no estudo feito sobre os Tapirapés: "Brincando se aprende".

Todo o desenvolvimento do plano didático é avaliado e discutido semanalmente. As reações desencadeadas, motivaçōes e acontecimentos especiais merecem lugar de destaque nestes encontros.

Existem fichas de observações e avaliações, feitas periodicamente com as crianças, acompanhando-se, de perto, o processo de aprendizagem e desenvolvimento.

Há integração de todos no processo educativo. A equipe da Abelhinha é composta por: Diretora (1), professoras (10), Psicóloga (1), Assistente Social (1), Nutricionista (1), Médico (1), Acadêmicos de Odontologia (vários), Merendeiras (2), Serventes (2), Monitoras (3), Guardião (1), Bibliotecários (2 voluntários) e a Comunidade.

Tem-se ainda, como objetivo principal, não só ensinar a criança, mas promover uma mútua troca de experiências entre : ESCOLA - CRIANÇAS-COMUNIDADE. Deste modo acredita-se que há realmente um processo educativo de base.

No ambiente onde as crianças do bairro vivem, as experiências que apoiam e estimulam o desenvolvimento emocional, social, intelec- 
tual e psicomotor, são restritas, pois as mesmas passam o dia na rua, na ausência dos pais que trabalham para o sustento da familia. As experiências adquiridas, desta forma, são freqüentemente desorganizadas e chocantes, pois o ambiente não é, por si próprio, educativo.

Assim sendo, a escola mantém como exigência a presença constante da família no processo de educação. As responsabilidades são divididas.

A Abelhinha, em muitos aspectos, encontra-se carente, mas essa carência nunca se tornou um obstáculo para interromper-se ou deixar-se de executar atividades educativas. Os pais, a comunidade em geral é que suprem muitas dessas dificuldades. Dando a eles uma parte da responsabilidade, é que se estimula e desenvolve a consciência da importância da ajuda na resolução dos problemas encontrados na educação.

Os alunos, em idade escolar, são matriculados na Unidade Educacional de $1 .^{\circ}$ Grau no próprio Coroado II, todos numa única turma, sendo que, na primeira impressão, essas crianças se sobressaem dos demais que não obtiveram a formação pré-escolar nos seguintes pontos: São mais críticos diante dos acontecimentos, são ativos e desinibidos e a aprendizagem ocorre de modo mais rápido.

Assim se processa um trabalho comunitário, com meios simples, em prol da formação pré-escolar. Com o apoio do INPA, LBA e outros órgãos colaboradores, a Abelhinha tem se dedicado a um objetivo específico: Promover um crescimento global e harmônico das potencialidades da criança.

Maria Inês Gasparetto Higuchi

Instituto Nacional de Pesquisas da Amazônia - INPA

Manaus - AM 